\title{
Biomechanical and ecological relationships of wing morphology of eight Chilean bats
}

\author{
Relaciones biomecánicas y ecológicas de la morfología alar de ocho quirópteros chilenos
}

\author{
MAURICIO CANALS ${ }^{1}$, BRUNO GROSSI ${ }^{1}$, JOSÉ IRIARTE-DÍAZ $^{2}$ \& CLAUDIO VELOSO ${ }^{1}$ \\ ${ }^{1}$ Departamento de Ciencias Ecológicas, Facultad de Ciencias, Universidad de Chile, Casilla 653, Santiago, Chile; \\ ${ }^{2}$ Department of Ecology and Evolutionary Biology, Brown University, Providence, Rhode Island 02912, USA; \\ * e-mail for correspondence: mcanals@uchile.cl
}

\begin{abstract}
In this study we compared the wing morphology of eight species of bats inhabiting Chile, including two previous studied species. We correlated the results with ecological information. Aspect ratio, wing span, wing area, wing loading and the second moment of area of humerus midshaft were estimated for the molossid Mormopterus kalinowskii, the phyllostomidae Desmodus rotundus and the vespertilionids Histiotus montanus, Histiotus macrotus, Lasiurus borealis, and Lasiurus cinereus.

The free-tailed bats T. brasiliensis and M.kalinowskii and D. rotundus, without uropatagyum, showed a low wing area, but whilst the molossids showed large aspect ratios, that of D. rotundus was only moderate. Desmodus rotundus showed the lowest wing span (relative to the expected one) and the largest wing loading. The second moment of area of the humerus midshaft of M. chiloensis is lower than the expected values from the allometric predictions, suggesting poorer resistance to bending and torsional forces. All other vespertilionids, showed a high second moment of area of humerus. This may be explained by the highly expensive form of locomotion, especially in species with high parasite power as a consequence of their long ears. The high $\mathrm{I}_{\mathrm{h}}$ of $D$. rotundus that can be explained by its high body mass which increase the torque produced by the weight and a low aspect ratio. The principal component analysis showed two orthogonal axes, the first correlated positively with the wing loading and negatively with the mass corrected wingspan and the second component with the aerodynamic efficiency parameter, AR. Four functional groups, one per quadrant, were described: (1) Desmodus rotundus, with high wing loading but low corrected wing span, was in the increased agility zone, with moderate power consumption during flight; (2) the molossids were located in the high speed flight and low total power zone, showing a high aerodynamic efficiency; (3) most of vespertilionids were in the zone of low speed but increased maneuverability, their aspect ratios and wing loading were relatively low; (4) Lasiurus cinereus was in the zone of fast speed flight and the low aspect ratio predicts an increased agility. The functional groups (2) and (3) exploit similar habitats but with different life styles, the molossids foraging in open areas at fast flight speed and the vespertilionids foraging in more wooded areas with maneuverable and slow flight. Desmodus rotundus clearly constitute a single group that may be related to flights from a far communal roost and their particular mode of locomotion.
\end{abstract}

Key words: bats, biomechanics, flight.

\section{RESUMEN}

Comparamos la morfología alar de ocho quirópteros chilenos, incluyendo dos especies previamente estudiadas. Correlacionamos los hallazgos con la información ecológica disponible. Estimamos la razón de aspecto, envergadura, la superficie, y la carga alar del molosido Mormopterus kalinowskii, el phyllostomidae Desmodus rotundus y los vespertilionidos Histiotus montanus, Histiotus macrotus, Lasiurus borealis, and Lasiurus cinereus. Los murciélagos de cola libre, T. brasiliensis, M. kalinowskii y D. rotundus, sin uropatagio, mostraron una baja superficie alar, pero mientras los molósidos mostraron alta razón de aspecto, la de D. rotundus fue solo moderada. Desmodus rotundus mostró la menor envergadura alar, relativa a su masa, y la mayor carga alar. El segundo momento del área del húmero de M. chiloensis es menor que lo esperado a partir de las predicciones alométricas, sugiriendo una pobre resistencia a la fuerzas de flexión y a la torsión. Todos los demás vespertiliónidos mostraron un alto segundo momento del área, lo que puede ser explicado por su energéticamente costosa forma de locomoción, especialmente en especias con alta potencia parásita a consecuencia de sus largas orejas. El alto $\mathrm{I}_{\mathrm{h}}$ que mostró $D$. rotundus puede ser explicado por su moderada razón de aspecto y por su elevada masa corporal que incrementa el torque producido por el peso. El análisis de componentes principales mostró dos ejes, el primero asociado positivamente con la carga alar y 
negativamente con la envergadura alar, y el segundo con la razón de aspecto. Se pudieron reconocer cuatro grupos funcionales, uno por cada cuadrante: (1) Desmodus rotundus, con alta carga alar pero baja envergadura, ubicado en la zona de alta agilidad y vuelo rápido con consumo moderado de energía; (2) los molósidos en la zona de alta velocidad de vuelo y bajo consumo; (3) la mayoría de los vespertiliónidos en la zona de alta maniobrabilidad y baja velocidad; (4)'L. cinereus, con alta velocidad y agilidad. Los grupos funcionales (2) y (3) explotan similares hábitat pero con diferentes formas de vida, los molósidos forrajeando en áreas abiertas a alta velocidad y los vespertiliónidos en áreas arboladas con vuelo maniobrable y lento. $D$. rotundus constituyó un grupo aparte relacionado con sus largos vuelos a sus sitios de descanso y su forma particular de locomoción.

Palabras clave: quiróptetos, biomecánica, vuelo.

\section{INTRODUCTION}

Wing morphology of bats is very diverse and has been correlated by one hand to biomechanical properties and energetic of flying, and on the other hand to ecological and behavioral aspect of flying, such as flight pattern, foraging behavior, habitat selection and prey size (Norberg 1987, 1994, Norberg \& Rayner 1987, Canals et al. 2001, Iriarte-Díaz et al. 2002).

Aerodynamic theory predicts that wing loading $\left(\mathrm{W}_{\mathrm{L}}=\mathrm{Mg} / \mathrm{S}\right.$, where $\mathrm{M}$ is the body mass, $g$ the gravity acceleration and $S$ the wing area), wing span (B) and aspect ratio ( $\mathrm{AR}=\mathrm{B}^{2} /$ S) are relevant parameters to determine flight performance. For example, during sustained flight lift (L) must be generated to balance body weight and thrust (T) to balance drag (D). Then, the power required to flight is $\mathrm{P}=\mathrm{Dv}=$ $\mathrm{Tv}$, where $\mathrm{v}$ is the flight speed. The cost of transport is also determined by lift and thrust. The lift is proportional to the flight speed squares times wing area $\left(\mathrm{L} \alpha \mathrm{v}^{2} \mathrm{~S}\right)$, then $\mathrm{v}$ is proportional to the square root of the wing loading $\left((\mathrm{Mg} / \mathrm{S})^{1 / 2}=\mathrm{W}_{\mathrm{L}}^{1 / 2}\right)$ (Norberg 1987). Hence, the wing loading may be considered as a parameter predictor of the lift and the flight speed.

The power required to flight may be decomposed in the power needed to produce aerodynamic force (aerodynamic power) and the power needed to oscillate the wings (inertial power: $\mathrm{P}_{\text {in }}$ ). The aerodynamic power may also be decomposed in (i) the parasite power $\left(\mathrm{P}_{\mathrm{par}}\right)$, the power needed to overcome the drag of the body, (ii) the profile power $\left(\mathrm{P}_{\mathrm{pro}}\right)$, necessary to overcome the drag of the wings, and (iii) the induced power $\left(\mathrm{P}_{\mathrm{I}}\right)$, necessary to generate lift and thrust. Thus, the total aerodynamic power is $\mathrm{P}=\left(\mathrm{P}_{\mathrm{par}}+\mathrm{P}_{\text {pro }}+\mathrm{P}_{\mathrm{I}}\right)+\mathrm{P}_{\text {in }}$. All these component of the power required to flight are correlated with $\mathrm{B}$ and $\mathrm{W}_{\mathrm{L}}$. Furthermore, the minimum drag $\left(D_{\min }\right)$ and the minimum power required to flight $\left(\mathrm{P}_{\min }\right)$ are inversely correlated to the aspect ratio: $\mathrm{D}_{\min }=$ $2 \mathrm{Mg}\left(\mathrm{C}_{\mathrm{r}} / \pi \mathrm{AR}\right)^{1 / 2}$ and $\mathrm{P}_{\text {min }}=\left[0.95(\mathrm{Mg})^{3 / 2} \mathrm{C}_{\mathrm{r}}{ }^{1 / 4}\right] /$ $\mathrm{B}(\mathrm{AR})^{1 / 4}$ where $\mathrm{C}_{\mathrm{r}}$ is the combined profile and parasite drag coefficient. Therefore, high aspect ratios are determinant in reducing the power needed to fly, and it is considered as a measurement of the aerodynamic efficiency (see Norberg 1994).

As flight is an expensive mode of locomotion, there should be strong selection for reduction of flight costs, favoring specific wing shapes. Energetics, however, is not likely the only critical design parameter for wings, and habitat and life style demands may be relevant, as well. If these demands conflict, wing shape may reflect functional compromises. For example, bats inhabiting densely vegetated environments need to be highly maneuverable and to be able to fly at low speeds, which are facilitated by low aspect ratios and wing loadings. This configuration, however, increases minimum drag and the power required to flight (Norberg 1987). Then if energetic costs of flight are relevant to the survival and reproduction of bats, we should expect to find narrow wings that minimize the work needed to fly by minimizing the induced power (Rayner 1979, Norberg 1987). These ecological and energetic demands are not compatible. Energetic demands predict bats will possess narrow wings, and habitat constraints predicts low wing loading and hence bats with large wing span, but large wings are very impractical in cluttered areas (Iriarte-Díaz et al. 2002).

Several studies have attempted to relate wing shape with flight patterns and foraging behavior in bats (Findley et al. 1972, Lawlor 1973, Norberg 1981, Baagoe 1987, Norberg 
1987, 1994, Norberg \& Rayner 1987, De la Cueva et al 1995, Spear \& Ainley 1997, Webb et al. 1998, Norberg et al. 2000). In Chile, only two species, Tadarida brasiliensis and Myotis chiloensis, have been studied from a morphofunctional perspective, looking for evidence of compromise solutions to energetic, ecological and behavioral demands (Canals et al. 2001, Iriarte-Díaz et al. 2002). In those studies both species presented morphological characteristics in agreement with their foraging behavior and life style. Myotis chiloensis, however, possessed an unusually low second moment of area of the humerus, which may be related to a reduction of wing mass and a decreased inertial power.

In this study we compared wing morphology of eight species of bats inhabiting Chile, including two previous studied species. We analyzed morphological differences among species from an energetic perspective based on aerodynamic theory. We also correlated the results with available ecological information, looking for evidence of compromise solutions to divergent energetic, ecological, and behavioral demands.

\section{MATERIAL AND METHODS}

We analyzed the molossid Mormopterus kalinowskii $(\mathrm{n}=2)$, the phyllostomidae Desmodus rotundus $(\mathrm{n}=1)$ and the vespertilionids Histiotus montanus $(\mathrm{n}=1)$, Histiotus macrotus $(\mathrm{n}=3)$, Lasiurus borealis $(\mathrm{n}$ $=3$ ) and Lasiurus cinereus $(\mathrm{n}=2)$. We included also the information of the molossid Tadarida brasiliensis and the vespertilionid Myotis chiloensis from previous studies (Canals et al. 2001, Iriarte-Díaz et al. 2002). We reported also values of five juveniles of Histiotus montanus $(\mathrm{n}=1)$ and Lasiurus cinereus $(\mathrm{n}=4)$. For the analyses, only the adults individuals were considered. Individuals were donated to us by Servicio Metropolitano de Salud del Medio Ambiente (SESMA).

Wing $\operatorname{span}(\mathrm{B}=$ the distance between the wing tips) was measured directly with calipers $( \pm 0.1 \mathrm{~mm})$ from individuals with outstretched wings. Great care was taken to keep the leading edges of the arm wings and parts of the hand wing along a straight line. Wing area $(\mathrm{S}=$ area of body between the wings and tail membrane) was estimated following Norberg (1994) by fully extending the right wing and the trailing edge of uropatagium aligned with the midline of the body, tracing the wing outline onto white paper and weighting it in an analytical balance $( \pm 0.1 \mathrm{mg})$.

External diameter $\left(D_{h}\right)$ and medullar cavity diameter $\left(\mathrm{d}_{\mathrm{h}}\right)$ of the humerus were measured from radiographs of the arm (Figure 1). Diameters were measured at midshaft. A distance focus-film of $1 \mathrm{~m}$ was used to avoid size distortion of actual bone dimensions. From these measurements, the following morphological parameters were computed: aspect ratio, wing loading, and second moment of area of the humerus at midshaft:

$I_{h}=\frac{\pi\left(D_{h}^{4}-d_{h}^{4}\right)}{64}$

a measure of the cross-sectional amount and geometrical distribution of material in a beam. This parameter is usually used as a proxy of bending bone strength (Wainwright et al. 1982, Biknevicius 1993). Wing span, wing area, and humeral second moment of area were compared with values predicted from allometric relationships (Kirkpatrick 1994). New allometric relationships were obtained from our measurements and compared with those of Kirkpatrick (1994). Also, a multiple regression analysis between $I_{h}$ and the predictors AR, B and $\mathrm{W}_{\mathrm{L}}$ was performed.

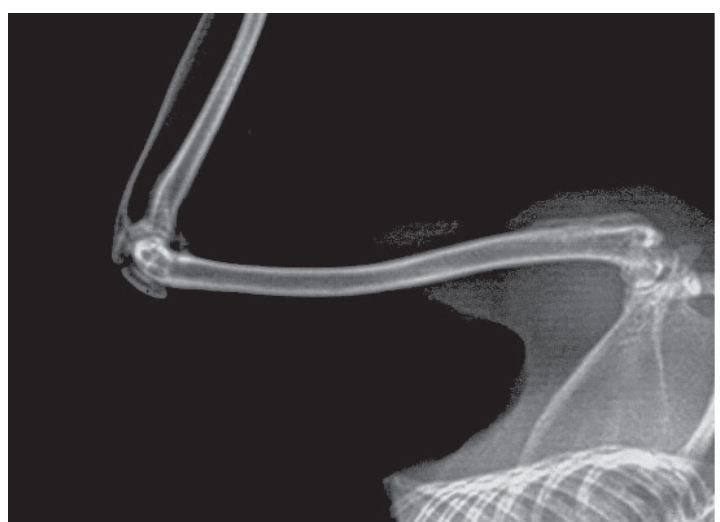

Fig. 1: Radiograph of the arm of Desmodus rotundus, showing the external diameter $\left(\mathrm{D}_{\mathrm{h}}\right)$ and medullar cavity diameter $\left(\mathrm{d}_{\mathrm{h}}\right)$ of the humerus, measures, used to estimate the second moment of area of the humerus at midshaft.

Radiografía del brazo de Desmodus rotundus, mostrando los diámetros externo $\left(\mathrm{D}_{\mathrm{h}}\right)$ y de la cavidad medular $\left(\mathrm{d}_{\mathrm{h}}\right)$ para el cálculo del segundo momento del área humeral. 
To characterize bat species from their morphological traits, a cluster analysis and a principal component analysis were done using body mass, $\mathrm{W}_{\mathrm{L}}, \mathrm{AR}$ and $\mathrm{B}$. All variables were standardized and B was corrected allometrically by dividing it for $\mathrm{M}_{\mathrm{b}}{ }^{1 / 3}$. From this last analysis the bats were ordered in four "functional" groups following the four quadrants defined by the two principal components.

To relate wing morphology with ecological and behavioral features of the bats, information obtained from literature was ordered in an "ecological" matrix that included reported habitat, dietary and social aspects (Table 1). Three levels of habitat (urban, woods and rocks); five dietary levels (Dipterans, Hymenopterans, Coleopterans, Lepidopterans and Blood); and two levels of social aspects (solitary and colonial) were recognized. A correspondence analysis between the functional groups and the ecological information was performed.

\section{RESULTS}

Individuals showed a wide range of body mass, from 3.1 in $M$. kalinowskii to $33.48 \mathrm{~g}$ in D. rotundus. Aspects ratios ranged from 5.76 in $M$. chiloensis to more than eight in the molossids T. brasiliensis and M. kalinowskii whilst $D$. rotundus showed the largest wing loading (Table 2). With the exception of $D$. rotundus, all species showed wingspans close to allometric predictions. As expected, $D$. rotundus which do not have uropatagium and the two free-tailed molossids $T$. brasiliensis and M. kalinowiskii showed low wing areas. The second moment of area of the humeral midshaft of $M$. chiloensis was lower than the expected and that of $T$. brasiliensis was similar to the expected from the allometry. In all other species $I_{h}$ were larger than the expected from the allometric relationships (Fig. 2-4).

TABLE 1

Ecological information of the molossids Tadarida brasiliensis and Mormopterus kalinowski, the phyllostomidae Desmodus rotundus and the vespertilionids Myotis chiloensis Histiotus montanus, Histiotus macrotus, Lasiurus borealis and Lasiurus cinereus; from Mann (1978), Redford \& Eisenberg (1989), and Ganz \& Martinez (2000).

Información ecológica de los molósidos Tadarida brasiliensis y Mormopterus kalinowski, el phyllostomidae Desmodus rotundus y los vespertilionidos Myotis chiloensis Histiotus montanus, Histiotus macrotus, Lasiurus borealis y Lasiurus cinereus; de Mann (1978); Redford \& Eisenberg (1989) and Ganz \& Martínez (2000).

\begin{tabular}{|c|c|c|c|c|c|c|c|c|c|c|}
\hline \multirow[t]{2}{*}{ Species } & \multicolumn{3}{|c|}{ Habitat } & \multicolumn{5}{|c|}{ Diet } & \multicolumn{2}{|c|}{ Social system } \\
\hline & $\mathrm{R}$ & $\mathrm{W}$ & $\mathrm{U}$ & $\mathrm{D}$ & $\mathrm{L}$ & $\mathrm{C}$ & $\mathrm{H}$ & $\mathrm{B}$ & S & $\mathrm{Cl}$ \\
\hline Myotis chiloensis & 1 & 1 & 1 & 1 & 0 & 0 & 0 & 0 & 0 & 1 \\
\hline Histiotus montanus & 1 & 1 & 1 & 1 & 1 & 0 & 0 & 0 & 0 & 1 \\
\hline Histiotus macrotus & 1 & 0 & 1 & 1 & 0 & 0 & 0 & 0 & 1 & 1 \\
\hline Lasiurus borealis & 0 & 1 & 0 & 1 & 1 & 1 & 0 & 0 & 1 & 0 \\
\hline Lasiurus cinereus & 0 & 1 & 0 & 0 & 1 & 1 & 1 & 0 & 1 & 0 \\
\hline Tadarida brasiliensis & 1 & 0 & 1 & 0 & 1 & 1 & 0 & 0 & 0 & 1 \\
\hline Mormopterus kalinowski & 1 & 0 & 0 & $0 *$ & $0 *$ & $0 *$ & $0 *$ & $0 *$ & 1 & 0 \\
\hline Desmodus rotundus & 1 & 0 & 0 & 0 & 0 & 0 & 0 & 1 & 0 & 1 \\
\hline
\end{tabular}

Abbreviations are: $\mathrm{R}=$ rocky environments, $\mathrm{W}=$ woods, $\mathrm{U}=$ urban environments, $\mathrm{D}=$ dipterans, $\mathrm{L}=$ lepidopterans, $\mathrm{C}=$ coleopterans, $\mathrm{H}=$ hymenopterans, $\mathrm{B}=$ hematophagous, $\mathrm{S}=$ solitary or groups with $<10$ individuals, $\mathrm{Cl}=\mathrm{colonial}$. Data from Mann (1978), Redford \& Eisenbreg (1989), and Ganz \& Martínez (2000).

Abreviaciones corresponden a: $\mathrm{R}=$ ambientes rocosos, $\mathrm{W}=$ bosques, $\mathrm{U}=$ ambientes urbanos, $\mathrm{D}=$ dípteros, $\mathrm{L}=$ lepidópteros, $\mathrm{C}=$ coleópteros, $\mathrm{H}=$ himenópteros, $\mathrm{B}=$ hematófagos, $\mathrm{S}=$ solitarios o grupos con $<10$ individuos, $\mathrm{Cl}=$ coloniales. Información obtenida de Mann (1978), Redford \& Eisenbrg (1989) y Ganz \& Martínez (2000).

* Information not available. 
TABLE 2

Summary of aerodynamic characteristics of the wings of eight species of bats; $\mathrm{Mb}=$ body mass, $\mathrm{B}$ = wingspan, $\mathrm{S}=$ wing area, $\mathrm{W}_{\mathrm{L}}=$ wing loading, $\mathrm{AR}=$ aspect ratio, and $\mathrm{I}_{\mathrm{h}}=$ second moment of area of humeral midshaft. Asterisks indicate juvenile individuals. In one adult individual of $H$. montanus it was not possible to estimate the wing area. Numbers in brackets indicate sample sizes

Resumen de las características aerodinámicas de las alas de ocho quirópteros; $\mathrm{Mb}=$ masa corporal, $\mathrm{B}=$ envergadura alar, $\mathrm{S}=$ superficie alar, $\mathrm{W}_{\mathrm{L}}=$ carga alar, $\mathrm{AR}$ = razón de aspecto, e $\mathrm{I}_{\mathrm{h}}=$ segundo momento del área humeral en la sección media. Los asteriscos indican individuos juveniles. En un H. montanus adulto no fue posible estimar la superficie alar. Los números entre paréntesis indican el número de réplicas

\begin{tabular}{|c|c|c|c|c|c|c|}
\hline Species & $\mathrm{M}_{\mathrm{b}}(\mathrm{g})$ & $\mathrm{B}(\mathrm{cm})$ & $\mathrm{S}\left(\mathrm{cm}^{2}\right)$ & $\mathrm{W}_{\mathrm{L}}\left(\mathrm{N} \mathrm{m}^{-2}\right)$ & $\mathrm{AR}$ & $\mathrm{I}_{\mathrm{h}}\left(\mathrm{cm}^{4} \times 10^{-6}\right)$ \\
\hline Myotis chiloensis (49)* & $6.76 \pm 0.18$ & $23.69 \pm 0.39$ & $98.29 \pm 3.47$ & $6.8 \pm 0.23$ & $5.76 \pm 0.16$ & $3.89 \pm 0.49$ \\
\hline Histiotus montanus (1) & 12.5 & 29.2 & - & - & - & 23.1 \\
\hline Histiotus macrotus (3) & $9.37 \pm 0.29$ & $29.67 \pm 0.58$ & $129.67 \pm 4.20$ & $7.08 \pm 0.19$ & $6.78 \pm 0.06$ & $21.17 \pm 3.52$ \\
\hline Lasiurus borealis (3) & $7.87 \pm 1.12$ & $25.37 \pm 2.49$ & $93.73 \pm 8.87$ & $8.20 \pm 0.46$ & $6.87 \pm 0.70$ & $12.68 \pm 9.30$ \\
\hline Lasiurus cinereus (2) & $19.55 \pm 6.58$ & $30.20 \pm 1.41$ & $165.45 \pm 52.07$ & $15.42 \pm 5.75$ & $5.72 \pm 1.29$ & $26.78 \pm 5.06$ \\
\hline Tadarida brasiliensis (27)* & $11.95 \pm 0.62$ & $28.65 \pm 0.63$ & $100.14 \pm 4.61$ & $11.56 \pm 0.66$ & $8.12 \pm 0.16$ & $11.15 \pm 2.61$ \\
\hline Mormopterus kalinowskii (2) & $3.10 \pm 1.13$ & $17.25 \pm 0.35$ & $32.4 \pm 2.26$ & $9.28 \pm 2.77$ & $9.20 \pm 0.27$ & $5.85 \pm 5.98$ \\
\hline Desmodus rotundus (1) & 33.48 & 33.5 & 167.23 & 19.61 & 6.71 & 68.3 \\
\hline Histiotus montanus $*(1)$ & 4.3 & 19.7 & 58.8 & 7.17 & 6.6 & 9.3 \\
\hline Lasiurus cinereus $*(4)$ & $12.23 \pm 2.71$ & $27.33 \pm 0.68$ & $93.50 \pm 8.18$ & $12.74 \pm 2.07$ & $8.01 \pm 0.44$ & $21.24 \pm 14.01$ \\
\hline
\end{tabular}

*From Iriarte-Díaz \& Canals (2002)

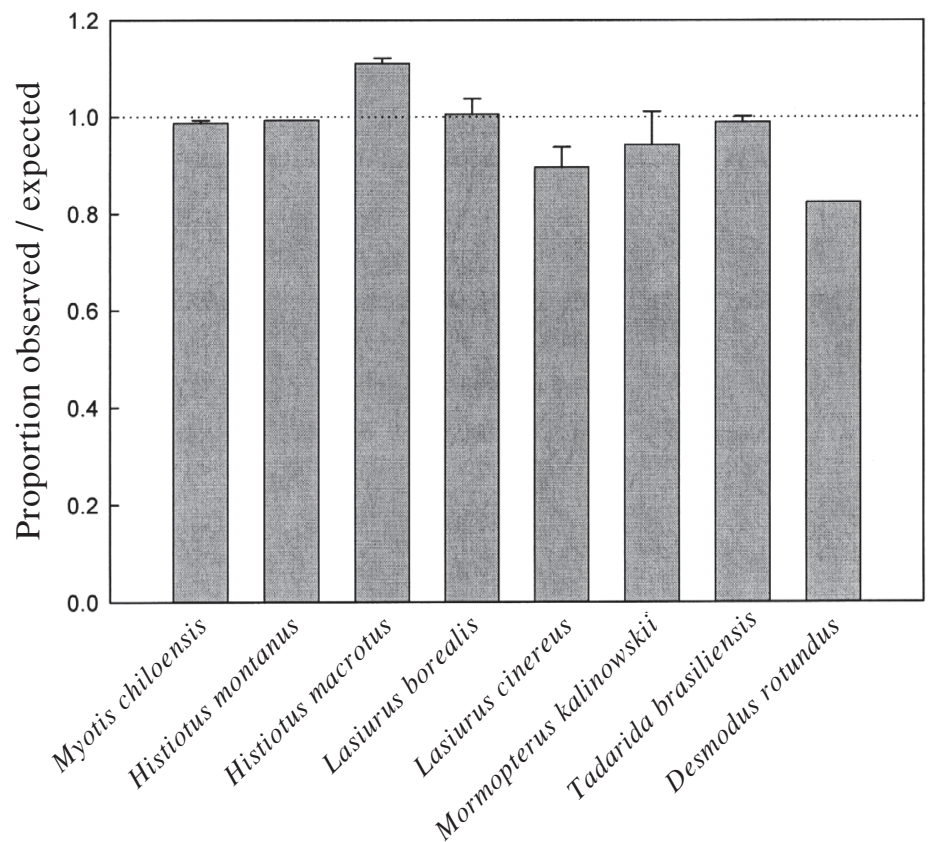

Species

Fig. 2: Ratios between observed values measured in this study and the expected values for wing span from the Kirkpatrick's allometric relationships (1994).

Razones entre los valores observados y esperados para la envergadura alar, a partir de las relaciones alométricas de Kirkpatrick (1994). 


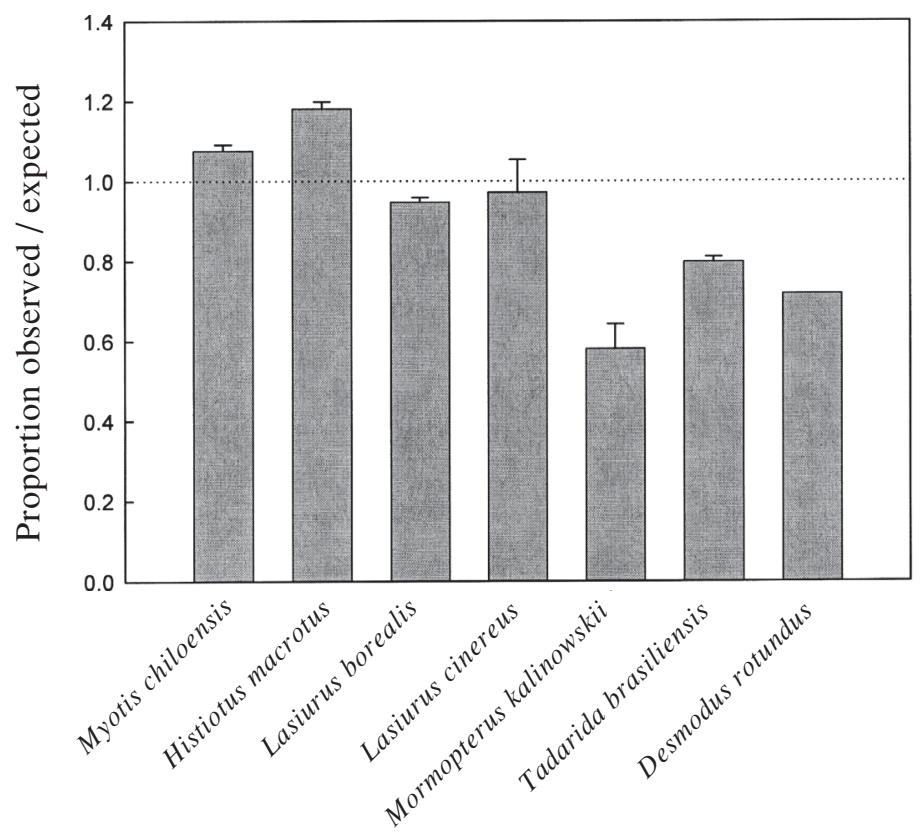

Species

Fig. 3: Ratios between observed values measured in this study and the expected values for wing area from the Kirkpatrick's allometric relationships (1994).

Razones entre los valores observados y esperados para el área alar, a partir de las relaciones alométricas de Kirkpatrick (1994).

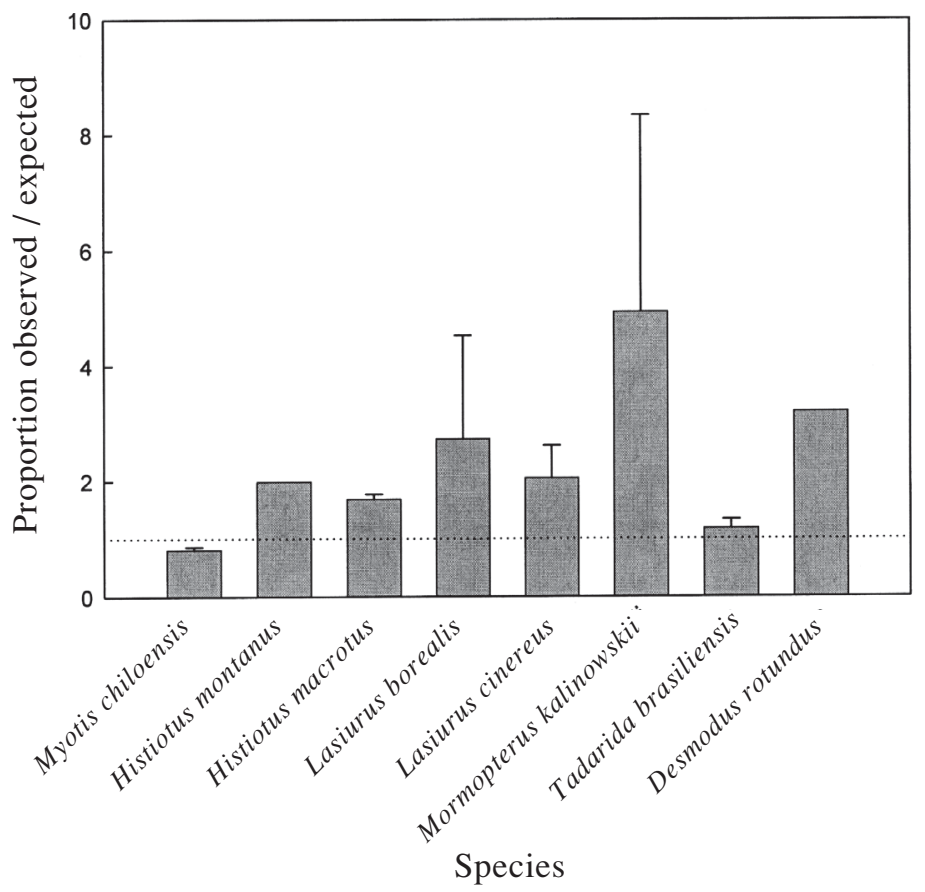

Fig. 4: Ratios between observed values measured in this study and the expected values for second moment of area of the humerus $\left(\mathrm{I}_{\mathrm{h}}\right)$ from the Kirkpatrick's allometric relationships (1994).

Razones entre los valores observados y esperados para el segundo momento del área del húmero ( $\mathrm{I}_{\mathrm{h}}$ ), a partir de las relaciones alométricas de Kirkpatrick (1994) 
The allometric relationships for the studied species were:

$B=14.226 \cdot M_{b}^{0.2678 \pm 0.0450} \mathrm{~B}$ in $\mathrm{cm}, \mathrm{M}_{\mathrm{b}}$ in $\mathrm{g}$, $\mathrm{R}^{2}=0.830, \mathrm{~F}_{1,6}=35.38, \mathrm{P}<0.01$

$S=24.085 \cdot M_{b}^{0.5984 \pm 0.1487}, \mathrm{~S}$ in $\mathrm{cm}^{2}, \mathrm{M}_{\mathrm{b}}$ in $\mathrm{g}$, $\mathrm{R}^{2}=0.717, \mathrm{~F}_{1.5}=16.19, \mathrm{P}=0.01$

$I_{h}=0.00015 \cdot B^{3.520 \pm 1.1073}, \mathrm{I}_{\mathrm{h}}$ in $\mathrm{cm}^{4}, \mathrm{~B}$ in $\mathrm{cm}$, $\mathrm{R}^{2}=0.582, \mathrm{~F}_{1,6}=10.75, \mathrm{P}=0.02$

In all cases the allometric exponents obtained by Kirkpatrick (1994) were within the 95 $\%$ confidence limits for our exponents.

Stepwise multiple regressions analyses showed that only wing loading is a good predictor of $\mathrm{I}_{\mathrm{h}}: I_{h}=3.977 \cdot W_{L}-22.884 \mathrm{R}^{2}=$ $0.683, \mathrm{~F}_{1,5}=13.94, \mathrm{P}=0.01$.

From cluster analysis, both groups, the vespertilonids $H$. macrotus, $M$. chiloensis and $L$. borealis and the molossids $T$. brasiliensis and M. kalinowskii scored similarly forming single groups, while the largest wing loadings, $L$. cinereus and $D$. rotundus formed another far single group (Fig. 5).

When body mass was included, two principal component were extracted accounting for $93 \%$ of the total variance. The first was related with body mass, wing loading and wingspan with factor loadings $0.95,0.97$ and -0.88 , respectively. The second component is mainly determined by AR with a factor loading 0.94.

If body mass was not included, a $95.57 \%$ of the total variance were explained by two principal component of similar structure. The first component ( $\lambda=1.883,62.77 \%$ of the variance) was related with inertial and size aspects: $C P_{1}=0.511 \cdot W_{L}-0.109 \cdot A R-0.506 \cdot B_{a}$, where $\mathrm{B}_{\mathrm{a}}$ is the allometrically corrected wingspan (dividing by $\mathrm{M}_{\mathrm{b}}{ }^{1 / 3}$ ). The factor loadings of $\mathrm{W}_{\mathrm{L}}$ and $\mathrm{B}_{\mathrm{a}}$ were 0.96 and -0.95 respectively. The second component $(\lambda=0.984,32.8 \%$ of the variance) was related with the wing form: $C P_{2}=0.058 \cdot W_{L}-0.994 \cdot A R-0.156 \cdot B_{a}$. The factor loading of AR was 0.98 in this component. Factor loadings did not vary significantly with varimax rotation. Based on the quadrants of the principal component analysis, four "functional" groups were defined: (1) D. rotundus; (2) the molossids $T$. brasiliensis and $M$. kalinowskii; (3) the vespertilionids $M$. chiloensis, H. macrotus and L. borealis; and (4) L. cinereus (Fig. 6).

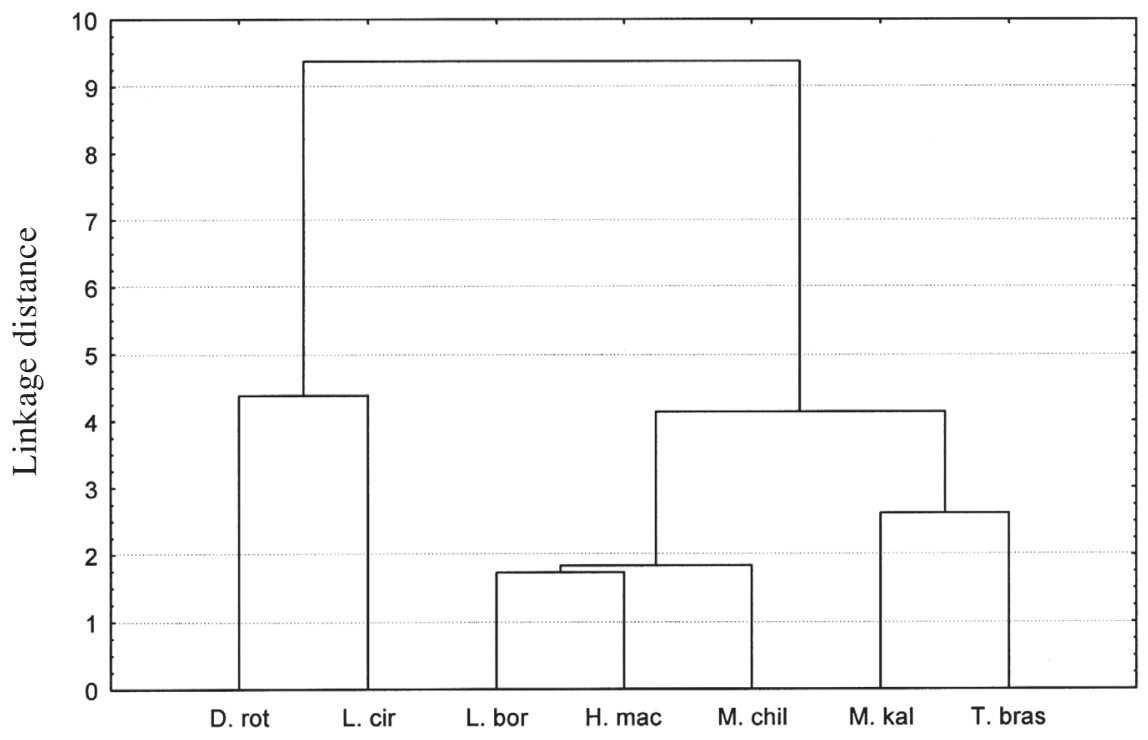

Fig. 5: Cluster diagram for seven bat species from the morphological characteristics: wingspan, wing area, wing loading and aspect ratio, using Euclidean distance and UPGMA grouping method. Abbreviations are: D. rot $=$ Desmodus rotundus, $\mathrm{L}$. cir $=$ Lasiurus cinereus, $\mathrm{L}$. bor $=$ Lasiurus borealis, H. mac = Histiotus macrotus, M. chil = Myotis chiloensis, M. kal = Mormopterus kalinowskii and $\mathrm{T}$. bras $=$ Tadarida brasiliensis.

Diagrama de agrupamiento de siete quirópteros a partir de las variables morfológicas: envergadura alar, área alar, carga alar y razón de aspecto, usando distancia Euclídea y el método de los pares no ponderados. Las abreviaciones corresponden a: D. rot $=$ Desmodus rotundus, L. cir $=$ Lasiurus cinereus, L. bor $=$ Lasiurus borealis, H. mac $=$ Histiotus macrotus, M. chil = Myotis chiloensis, M. kal= Mormopterus kalinowskii and T. bras = Tadarida brasiliensis . 


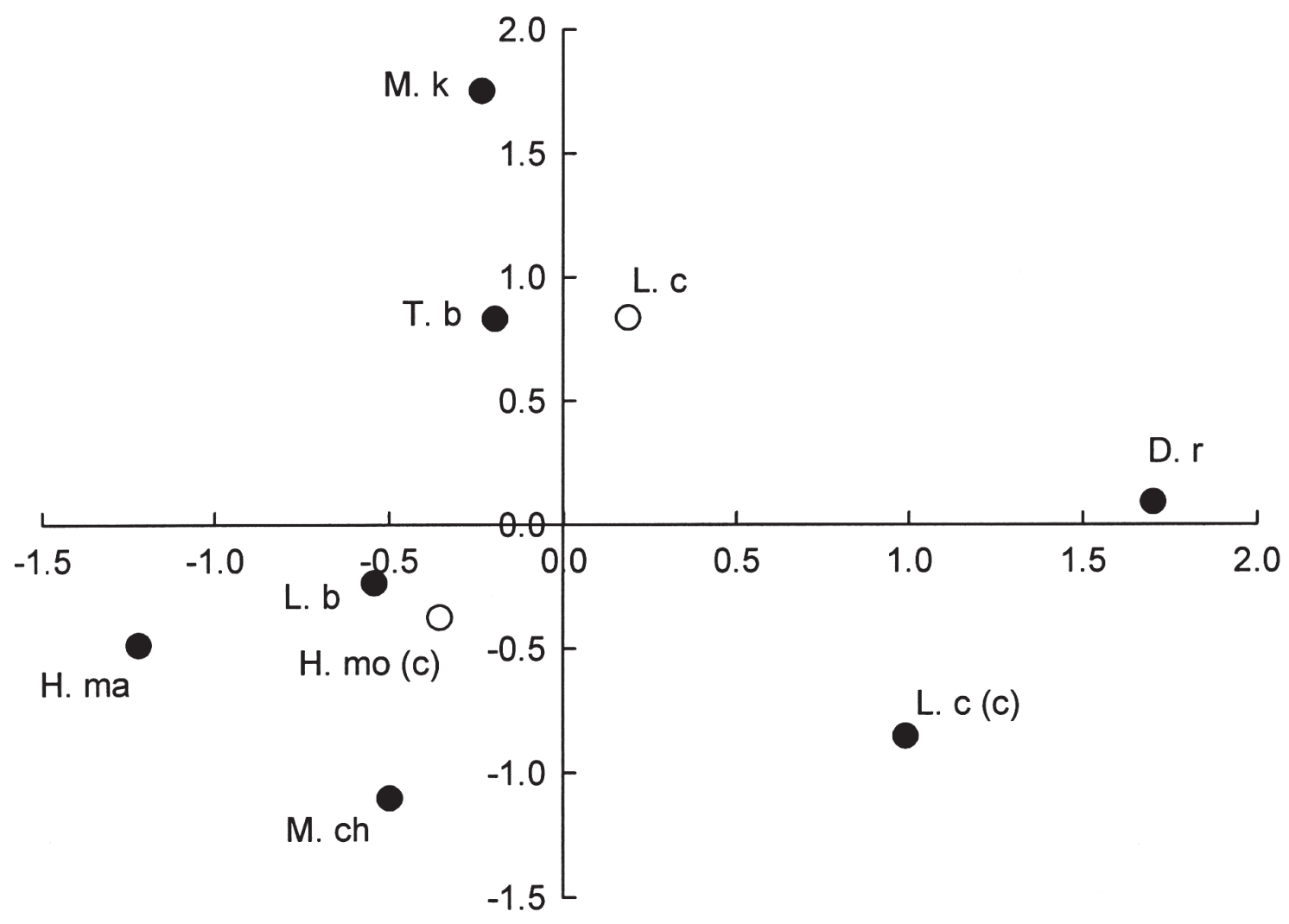

Fig. 6: Principal component plot for the bat species: Desmodus rotundus (Dr), Lasiurus cinereus (Lc), Lasiurus boreales (Lb), Histiotus macrotus (Hma), Histiuotus montanus (Hmo), Myotis chiloensis (Mch), Mormopterus kalinowskii (Mk) and Tadarida brasiliensis (Tb). The symbol (c) indicates juvenile individuals and they were not considered to comput the principal components. Broadly, the zone superior, close to the second component axis is characterized by high aerodynamic efficiency; the inferior left quadrant is a zone characterized by slow and energetically expensive flight; the right superior quadrant is a zone of increased agility and the inferior right quadrant combines agility with high speed.

Gráfico de componentes principales para las especies Desmodus rotundus (Dr), Lasiurus cinereus (Lc), Lasiurus boreales (Lb), Histiotus macrotus (Hma), Histiuotus montanus (Hmo), Myotis chiloensis (Mch), Mormopterus kalinowskii (Mk) and Tadarida brasiliensis (Tb). El símbolo (c) indica individuos juveniles, los cuales no fueron considerados para los cálculos de los ejes. En términos generales, la zona superior, cerca del segundo componente indica un vuelo eficiente, de bajo costo; el cuadrante inferior izquierdo se asocia a vuelo lento y costoso, el cuadrante superior derecho con una mayor agilidad de vuelo y el inferior derecho combina agilidad y alta velocidad.

In the correspondence analysis, the two first dimensions account for $86.02 \%$ of the total inertia, a measurement of the association among the functional groups and the ecological information, However the information was insufficient to found significant association $\left(\chi^{2} 27\right.$ $=26.124, \mathrm{P}>0.05)$, indicating that at light of the available information, the analyzed species form a very homogeneous group. Some patterns, however, were identified from the dimensional graphs (Fig. 7). Solitary habits were associated with woodlands habitats and with diet composed of lepidopterans and coleopterans. An association was also found between urban environments and dipterans diets. Rock environments showed an association with colonial habits. Furthermore, groups (2) and (3) scored very similar, while $L$. cinereus grouped with hymenopteran dietary habits and obviously $D$. rotundus grouped with blood ingestion. 
(A)

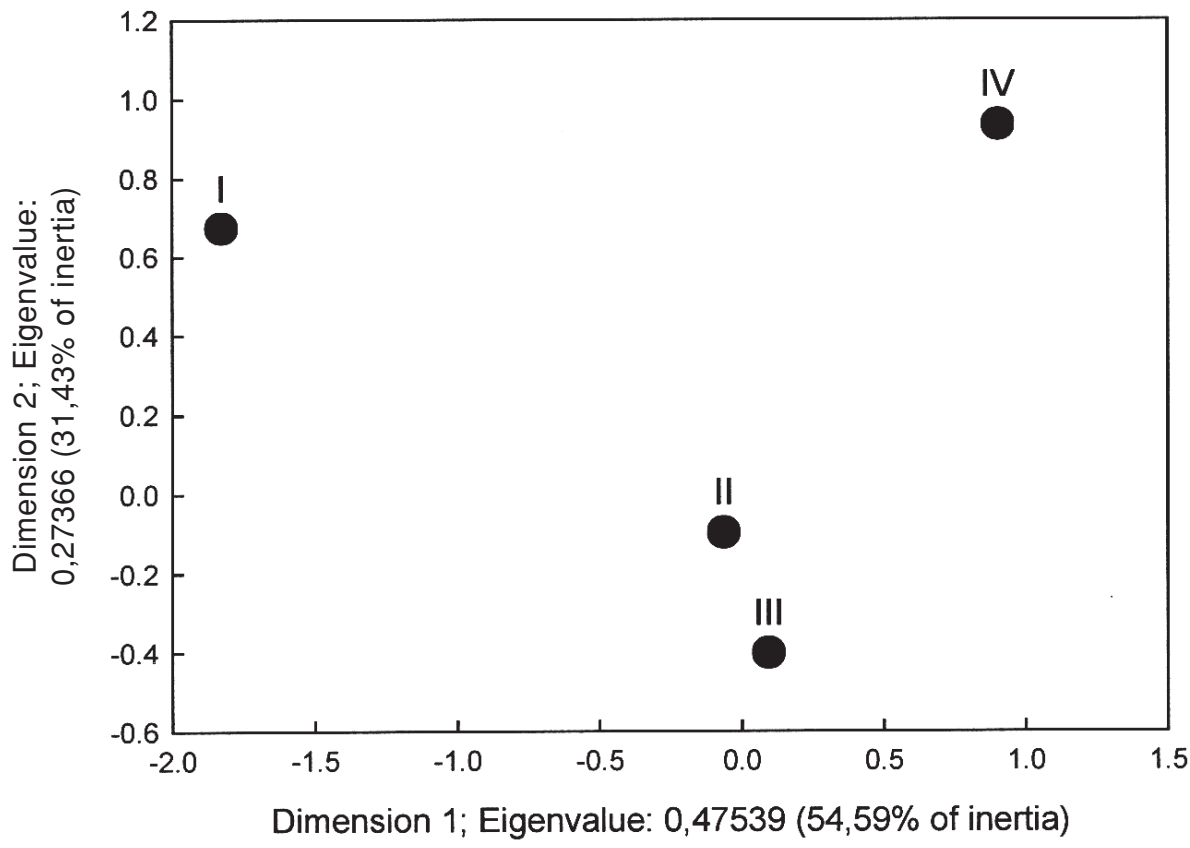

(B)

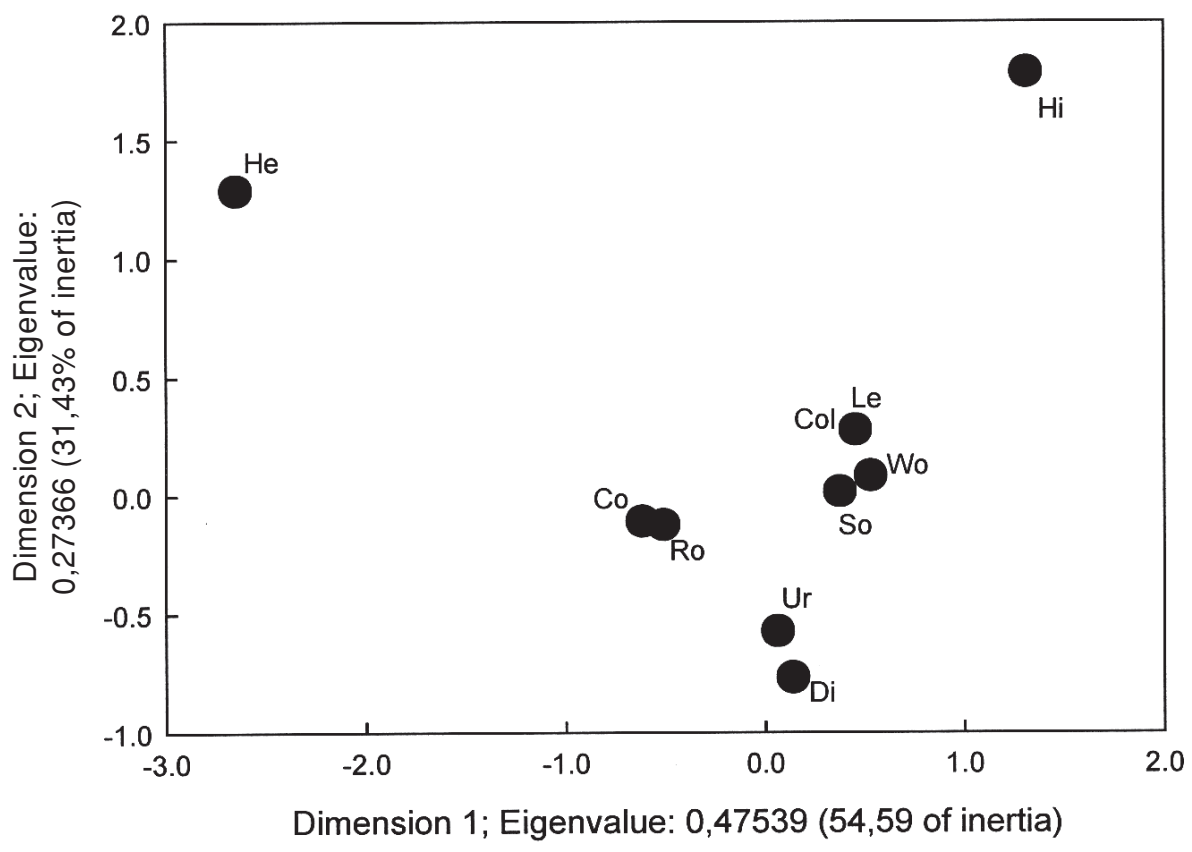

Fig. 7: Two dimensional correspondence plot relating ecological characteristics with the four "functional" groups derived from the principal component analysis. (A) Group I: D. rotundus, Group II: molossids; Group III: most of vespertilionids (see text); Group IV: L. cinereus. (B) Diets: He: Blood; Hi: himenoptera; Le: Lepidopterans; Co: coleopterans; Di: Dipterans; Habitats: Wo: Woods; Ro: Rocks; Ur: Urban; Social habits: Co: Colonial; So: Solitary.

Gráfico bidimensional de correspondencia entre las características ecológicas y los cuatro grupos "funcionales" derivados del análisis de componentes principales. (A) Grupo I: 'D. rotundus, Grupo II: molósidos; Grupo III: la mayoría de los vespertiliónidos (ver texto); Grupo IV: L. cinereus. (B) Dietas: He: Sangre; Hi: Himenópteros; Le: Lepidópteros; Co: Coleópteros; Di: Dípteros; Habitats: Wo: Bosques; Ro: Rocas; Ur: Urbanos; Hábitos sociales: Co: Coloniales; So: Solitarios 


\section{DISCUSSION}

As expected, the free tailed bats T. brasiliensis and M.kalinowskii and the phyllostomidae $D$. rotundus, which do not have uropatagyum, showed a small wing area, but while molossids showed stylized wings with large aspect ratios, that of $D$. rotundus was only moderate. Moreover $D$. rotundus showed the shortest wing span (relative to the expected one) and the largest wing loading. These results are similar to reported results (Norberg \& Rayner 1987, Kirkpatrick 1994). Tadarida brasilensis and L. borealis also showed $\mathrm{AR}, \mathrm{W}_{\mathrm{L}}$ and $\mathrm{S}$ values similar to previously published results (Norberg \& Rayner 1987). Only our B, S and AR values for adults individuals of $L$. cinereus were slightly lower than reported values $\left(39.8 \mathrm{~cm}, 196 \mathrm{~cm}^{2}\right.$ and 8.1, respectively; Norberg \& Rayner 1987). This AR value is similar to that of our juvenile individuals (8.01). To our knowledge, no previous report exists for species of the genus Histiotus and M. kalinowskii.

Aerodynamic theory predicts that minimum flight speed scales proportional to $\mathrm{W}_{\mathrm{L}}{ }^{0.5}$, and therefore only bats with low wing loading can fly slowly, while bats with high wing loading would fly at higher minimum speeds (Norberg 1994). Average flight speeds between $6 \mathrm{~m} \mathrm{~s}^{-1}$ (Hayward \& Davies 1964) and $11.3 \mathrm{~m} \mathrm{~s}^{-1}$ (Svobova \& Choate 1987) have been reported for $T$. brasiliensis, and average speed $5.1 \mathrm{~m} / \mathrm{s}$ for L. cinereus (Hayward \& Davies 1964) and $3.5 \mathrm{~m} \mathrm{~s}^{-1}$ for L. borealis (Patterson \& Hardin 1969). Wing loadings of these species were $11.56,15.2$ and $8.2 \mathrm{~N} \mathrm{~m}^{-2}$ respectively, showing a tendency similar to that observed for average flight speed. However reported speeds for Lasiurus species, which have high wing loadings are below the recorded average speed for 44 species of bats $\left(5.65 \mathrm{~m} \mathrm{~s}^{-1}\right)$ (Norberg 1987). This is because wing loading is not the only factor determining the fly speed. Instead there are several limitations imposed by the increased parasite and profile energetic power needed to flight at high speed (Speakman \& Thomas 2003). Also induced drag from ears in long-eared bats such as Histiotus species might be a restriction for fast flight.

Aspect ratio can be interpreted as a measure of the aerodynamic efficiency of flight (Norberg 1994). Aerodynamic theory predicts that total flight power is obtained with high aspect ratio wings by decreasing profile power in fast flight and by decreasing induced power in slow flight (Rayner 1982, Norberg 1987). The high aspect ratio observed in molossids, and juvenile individuals of $L$. cinereus would allow a fast and economical flight, and it would be consistent with the requirements of species that fly over long distances. The low aspect ratio of the rest studied species indicates a relative more expensive flight and probably slower minimum flight speeds. However, most of the aerodynamic theory is based on the assumption of a constant efficiency of translating metabolic to mechanical power. If that were not true, the inferences from flight energy cost based on morphology provided only a poor idea of cost of flight. Fortunately the small number of individuals bats across three species that have been analyzed in this way suggest that bats broadly conform to the expectations of aerodynamics models (Speakman \& Thomas 2003).

During active flight, the skeleton of the upper extremities of bats must resist the dynamics load of flapping. Wings bones in bats are not aligned with the wing's center of pressure, therefore the main forces exerted on the humerus are torsional (Swartz et al. 1992, Biewener \& Dial 1995). The ability of a bone to withstand torsional forces is proportional to the polar second moment of area $(\mathrm{J})$ of the bone's cross section, which is twice the second moment of area for a bone of circular crosssection (Swartz 1997). The second moment of area of the humerus midshaft of $T$. brasiliensis was similar to the expected, while that of $M$. chiloensis was lower than the expected values from the allometric predictions (Kirckpatrick 1994), suggesting poorer resistance to bending and torsional forces. Bat wing bones have the lowest safety factors among vertebrates, estimated at about 1.4 during hovering (Kirkpatrick 1994). They are therefore susceptible to damage to the wing skeleton during flight, particularly during hovering in which the wing beat and mechanical demands are supposed to be the highest (Rayner 1987). The low second moment of area of the midshaft humerus in $M$. chiloensis, a bat with low aspect ratio and wing loading and probably low and energetically expensive flight, may be a consequence of a reduction of the cortical cross section of the humerus, decreasing the wing 
mass and hence the inertial power (Iriarte-Díaz et al. 2002). This reduction might as well improve flight maneuverability (defined as minimum turning radius the animal can attain) and agility (maximum roll acceleration during initiation of a turn, a measure of ability to alter flight path) (Tholleson \& Norberg 1991).

All other vespertilionids, $H$. montanus, $H$. macrotus, L. borealis and L. cinereus showed second moment of area of midshaft humerus larger than the expected values from the Kirkpatrick's allometric relationship. Although the number of individuals studied was low to attain general conclusions, the large second moment of area might be explained by the highly expensive form of locomotion at low flight speed as consequence of low aspect ratios but high wing span, specially in the two Histiotus species with high parasite power as a consequence of their long ears. Bats flying at low speed increase aerodynamic torque by low aspect ratio (broad wings) and large wing span (Iriarte-Díaz et al. 2002). The vampire bat $D$. rotundus also showed a very high $\mathrm{I}_{\mathrm{h}}$ that can be explained by its high body mass which increase the torque (the product of the force and the moment arm) and a low aspect ratio. The body mass is specially relevant in a species that uses occasionally a quadruped mode of locomotion (Mann 1978).

The high $\mathrm{I}_{\mathrm{h}}$ of $M$. kalinowskii is a consequence of a thick cortical annulus of the humerus and is a surprise because this is a small bat that probably flies at fast speed, and with low total flight power. Although the average safety factor of the humerus of bats is 1.4, some bats such as Rhogeessa tumida, a bat of body mass $(4 \mathrm{~g})$ and wing span similar to $M$. kalinowskii, have safety factors between 1.43 and 4.57 for bending stress during flapping flight, and between 19.3 and 194.0 for shear stress (Kirkpatrick 1994). Those are very large numbers, compared with safety factors around 2 observed in other vertebrates (Biewener 1990, Kirkpatrick 1994). However, the low number of studied individuals is insufficient to derive more general conclusions.

Like in birds, all morphological characteristics of the wing obtained in this study, $\mathrm{B}, \mathrm{S}$ and $\mathrm{I}_{\mathrm{h}}$, scales nearly geometrically with body mass or wingspan, in agreement with previous reported data of Kirkpatrick (1994). This author found: $B \alpha M^{0.33} ; S \alpha M^{0.59} ; I_{h} \alpha B^{4.42}$ similar to our exponents $0.267 \pm 0.05,0.598 \pm$ 0.149 , and $3.483 \pm 1.19$ and also to the expected values by geometrical similitude $1 / 3$, $1 / 2$, and 4 , respectively. When performed a stepwise linear regression analysis the only good predictor of $I_{h}$ was the wing loading, a load factor that scales with $\mathrm{M}_{\mathrm{b}}{ }^{1 / 3}$. The humerus must be strong enough to withstand bending and torsional moments generated by lifting forces acting on the wing during flight and it must resist the moments imparted to it by the distal portion of the wing. Drag also imposes moments on the wing, but the drag-based moments are much smaller than the weight induced moments during flight (Kirkpatrick 1994). In gliding, each wing must resist half of the body mass and hence the bending and torsional moments on the wings are proportional to the product of the body mass and the arm length (Kirkpatrick 1994).

Cluster analysis revealed morpho-functional similarities between the vespertilonids $H$. macrotus, $M$. chiloensis and $L$. borealis and the molossids $T$. brasiliensis and M. kalinowskii, whereas $L$. cinereus and $D$. rotundus were probably grouped by their high wing loadings. A principal component analysis showed that the first component correlates positively with the wing loading and negatively with the mass corrected wingspan. The second component represented the aerodynamic efficiency parameter AR, agreeing with the results for 257 species of Norberg \& Rayner (1987). This was consistent with the cluster analysis showing four functional groups, one per quadrant: (1) $D$. rotundus, with high wing loading but low corrected wing span; (2) the stylized free-tailed molossids $T$. brasiliensis and M. kalinowskii; (3) the vespertilionids $M$. chiloensis, $H$. macrotus and L. borealis, in which the juvenile of H. montanus may be included; and (4) adults of $L$. cinereus (Fig. 5). In the graphic our studied species showed a pattern distribution similar to that of Norberg \& Rayner (1987).

Desmodus rotundus was in the increased agility area, and like other desmodontines probably have fast flight with moderate power consumption (Norber \& Rayner 1987). The molossids were in the zone with reduced power and cost of transport. These are widely considered to be the most highly adapted bats, and are characteristically specialized for hawking of high-flying insects. This unusual 
small wing area, and high wing loading implies fast flight relative to other bats of comparable body size, and an inability to manoeuvre within clutter (Norberg \& Rayner 1987).

Vespertilionidae is the largest bat family, including more than 300 , most of them insectivorous (Kunz \& Fenton 2003). They form a very diverse group in relation to their wing morphology, and include bats with a wide range of wing loadings, but in general with moderate to low aspect ratios. Excepting $L$. cinereus all studied vespertilionids (III group) were in the zone of low speed but increased maneuverability, with relatively low aspect ratios and wing loadings. This result agrees with that has been reported for most of the Myotis species (Norberg \& Rayner 1994), small bats that fly short distances and hover to glean insect from surfaces (Swift \& Racey 1983). Lasiurus cinereus, showed developmental differences in their wing morphology. Juveniles showed higher aspect ratios than adults and that was lower than reported by Norberg \& Rayner (1987). However our results for this species were consistent with field observations reporting fast straight flights in open areas (Barclay 1985), but making rapid swoops near the ground (Norberg \& Rayner 1987). Its high wing loading predicts fast speed flights while the low aspect ratio predicts an increased agility.

Both molossids, T. brasiliensis and $M$ kalinowskii were located in the high speed flight and low total power to fly zone, showing a high aerodynamic efficiency as largely recognized for this family (Norberg \& Rayner 1987).

The scarceness of ecological studies of bats in Chile (Jaksic 1997) and the correlation nature of the last analysis did not allow to infer causal relationships. However, comparative correlational approaches have produced the core of our understanding of the relationships between ecology and morphology of bats (Swartz 2003). From the correspondence analysis, some patterns emerged. The functional groups (2) and (3) (molossids and most of vespertilionids) are grouped very close together exploiting similar habitats, but with different life styles: molossids foraging in open areas at fast flight speed and vespertilionids foraging in woodland areas where maneuverable and slow flight would be required. Woodlands allow solitary modes of existence offering numerous roosting and nesting sites, while, in Chile, rock and urban environments appear to be preferred by bats for colonial habits. However, in other places bats can form large colonies in practically all habitats such as woodlands, rocks and urban environments (Kunz \& Fenton 2003).

D. rotundus clearly conforms a single group for their particular morphological and ecological characteristics. Its high wing loading and moderate aspect ratio predict a high flight speed with moderate power consumption that might be related to long flights from its communal roost that can be about $3.4 \mathrm{~km}$ long (Wilkinson 1985). Short flying times may be a useful way to save energy in species with slow blood intake (McNab 1973). Lasiurus cinereus also grouped alone from both ecological and morphological perspectives. The morphologic characteristics predict fast but agile flight in open or relatively closed areas (short wingspan) while the ecological data suggest woodland habitats and a diet based mainly in coleopterans and lepidopterans. The presence of hymenopterans in its diet could be indicative of more diurnal habit than other vespertilionids, such as Histiotus species.

\section{ACKNOWLEDGEMENTS}

We thank Dr. Miriam Favi for facilitating the specimens. This work was founded by FONDECYT 1040649 grant.

\section{LITERATURE CITED}

BAAGOE HJ (1987) The Scandinavian bat fauna: adaptative wing morphology and free flight in the field. In: Fenton MB, P Racey \& JMV Rayner (eds) Recent advances in the study of bats: 57-75. Cambridge University Press, Cambridge, United Kingdom.

BARCLAY RMR (1985) Long- versus short-range foraging strategy of hoary (Lasiurus cinereus) and sylver haired (Lasionycteris noctivagans) bats and the consequences for prey selection. Canadian Journal of Zoology 63: 2507-2515.

BIEWENER AA (1990) Biomechanics of mammalian terrestrial locomotion. Science 250: 1097-1103.

BIEWENER AA \& KP DIAL (1995) In vivo strain in the humerus of pigeons (Columba libia) during flight. Journal of Morphology 225: 61-75.

BIKNEVICIUS AR (1993) Biomechanical scaling of limb bones and differential limb in caviomorph rodents. Journal of Mammalogy 74: 95-107. 
CANALS M, J IRIARTE-DÍAZ, R OLIVARES \& FF NOVOA (2001) Comparación de la morfología alar de Tadarida brasiliensis (Chiroptera: Molossidae) y Myotis chiloensis (Chiroptera: Vespertilionidae), representantes de dos diferentes tipos de vuelo. Revista Chilena de Historia Natural 74: 699-704.

DE LA CUEVA H, MB FENTON, MBC HICKEY \& RW BLAKE (1985) Energetic consequences of flight speeds of foraging red and hoary bats (Lasiurus borealis and Lasiurus cinereus; Chiroptera: Vespertilionidae). Journal of Experimental Biology 198: 2245-2251.

FINDLEY JS, EH STUDIER \& DE WILSON (1972) Morphologic properties of bat wings. Journal of Mammalogy 53: 429-444.

GANZ A \& R MARTÍNEZ (2000) Orden Chiroptera. In: Muñoz A \& J Yáñez (eds) Mamíferos de Chile: 5366. CEA Ediciones, Valdivia, Chile.

HAYWARD B \& R DAVIS (1964) Flight speeds in western bats. Jounal of Mammalogy 45: 236-242.

IRIARTE-DÍAZ J, FF NOVOA \& M CANALS (2002) Biomechanic consequences of differences in wing morphology between Tadarida brasiliensis and Myotis chiloensis. Acta Theriologica 47: 193-200.

JAKSIC FA (1997) Los mamíferos poco conocidos. In: Jaksic J (ed) Ecología de los vertebrados de Chile: 126-129. Ediciones Universidad Católica de Chile, Santiago, Chile.

KIRKPATRICK SJ (1994) Scale effects on the stresses and safety factors in the wing bones of birds and bats. Journal of Experimental Biology 190: 195-215.

KUNZ TH \& MB FENTON (2003) Bat ecology. University of Chicago Press, Chicago, Illinois, USA. 779 pp.

LAWLOR TE (1973) Aerodynamic characteristics of some Neotropical bats. Journal of Mammalogy 35: 103104.

MCNAB BK (1973) Energetics and the distribution of vampires. Journal of Mammalogy 54: 131-144.

MANN G (1978) Los pequeños mamíferos de Chile. Gayana Zoología (Chile) 40: 1-342.

NORBERG RA (1981) Optimal flight speeds in birds when feeding young. Journal of Animal Ecology 50: 473477.

NORBERG UM (1987) Wing form and flight mode in bats. In: Fenton MB, P Racey \& JMV Rayner (eds) Recent advances in the study of bats: 43-57. Cambridge University Press, Cambridge, United Kingdom.

NORBERG UM (1994) Wing design, flight performance and habit use in bats. In: Wainwright PC \& SM Reilly (eds) Ecological morphology: integrative organismal biology: 205-239. University of Chicago Press, Chicago, Illinois, USA.

NORBERG UM \& JMV RAYNER (1987) Ecological, morphology and flight in bats (Mammalia: Chiroptera): Wing adaptations, flight performance, foraging strategy and echolocation. Philosophical Transactions of the Royal Society of London B 316: 335-427.

Associate Editor: Francisco Bozinovic

Received December 2, 2004; accepted March 1, 2005
NORBERG UM, AP BROOKE \& WJ TREWHELLA (2000). Soaring and non-soaring bats of the family Pteropodidae (flying foxes, Pteropus spp.): wing morphology and flight performance. Journal of Experimental Biology 203: 651-664.

PATERSON A \& J HARDIN (1969) Flight speed of five species of vespertilionid bats. Journal of Mammalogy 50: 152-153.

RAYNER LMV (1979) A new approach to animal flight mechanics. Journal of Experimental Biology 80: 1754.

RAYNER LMV (1982) Avian flight energetics. Annual Review of Physiology 44:109-119.

RAYNER LMV (1987) The mechanics of flapping flight in bats. In: Fenton MB, P Racey \& JMV Rayner (eds) Recent advances in the study of bats: 23-42. Cambridge University Press, Cambridge, United Kingdom.

REDFORD KH \& JF EISENBERG (1989) Mammals of the Neotropics: the southern cone. University of Chicago Press, Chicago, Illinois, USA. 431 pp.

SPEAKMAN JR \& DW THOMAS (2003) Physiological energetics of bats. In: Kunz TH \& MB Fenton (eds) Bat ecology: 430-478. University of Chicago Press, Chicago, Illinois, USA.

SPEAR LB \& DG ANLEY (1997) Flight behavior of seabirds in relation to wind direction and morphology. Ibis 139: 221-233.

SVOBOVA PL \& JR CHOATE (1987) Natural history of the Brazilian free-tailed bat in the San Luis Valley of Colorado. Journal of Mammalogy 68: 224-234.

SWARTZ SM (1997) Allometric pattering in the limb skeleton of bats: implications for the mechanics and the energetic of powered flight. Journal of Morphology 234: 277-294.

SWARTZ SM, MB BENNET \& DR CARRIER (1995) Wing bones stresses in free flying bats and the evolution of skeletal design for flight. Nature 359: 726- 729.

SWIFT SM \& PA RACEY (1983) Resource partitioning in two species of vespertilionid bats(Chiroptera) occupying the same roost. Journal of Zoology London 200: 249-259.

THOLLESON M \& UM NORBERG (1991) Moment of inertia of bat wings and body. Journal of Experimental Biology 158: 19-35.

WAINGWRIGHT SA, WD BIGGS, JD CURREY \& JM GOSLINE (1982) Mechanical design in organisms: 1-423. Princeton University Press, Princeton, New Jersey, USA.

WEBB PI, JA SEDGELEY \& FJO'DONELL (1998) Wing shape in New Zealand lesser short-tailed bats (Mystacina tuberculata). Journal of Zoology, London 246: 462-465.

WILKINSON GS (1985) The social organization of the common vampire bat. I. Pattern and cause of association. Behavioral Ecology and Sociobiology 17:111-121. 